\title{
Potential of Concentrating Solar Power Plants for the Combined Production of Water and Electricity in MENA Countries
}

\author{
Massimo Moser, Franz Trieb, Tobias Fichter \\ Institute of Technical Thermodynamics \\ German Aerospace Center (DLR) \\ Email: massimo.moser@dlr.de
}

Cite as: Moser, M., Trieb, F., Fichter, T., Potential of Concentrating Solar Power Plants for the Combined Production of Water and Electricity in MENA Countries, J. sustain. dev. energy water environ. syst., 1(2), pp 122-140, 2013, DOI: http://dx.doi.org/10.13044/j.sdewes.2013.01.0009

\begin{abstract}
The widening gap between consumption and availability of water poses a serious threat to a sustainable socioeconomic development of the Middle East and North Africa (MENA) countries and calls for an even larger augmentation of water supply using seawater desalination. However, these plants are affected by high specific energy consumption, while the uncertainty about fossil fuel prices in the future represents a severe problem. Within this study long-term scenarios for water and electricity demand based on potential assessment of renewable energies have been developed. The results provide baseline information for decision makers for the establishment of a favourable framework for the deployment of concentrated solar power and desalination plants. Finally, this paper points out the importance to start a paradigm change in water and electricity supply as soon as possible, in order to meet the requirements for low cost water and electricity and to avoid conflicts related to water scarcity.
\end{abstract}

\section{KEYWORDS}

Solar Desalination, Renewable Energy, MENA, Water Supply Scenario, CSP, Financing Renewable Technologies

\section{INTRODUCTION}

In the MENA region, the combination of dry climatic conditions, increasing water demand due to population and economic growth, as well as dated water supply systems often result in water scarcity. In many cases groundwater is overused in order to satisfy the demand. If the natural replenishment rate of the aquifers is not able to compensate for water extraction, this practice results in descending groundwater levels. Furthermore high underground water pumping rates leads to seawater intrusion to aquifers in coastal areas, making this water no longer suitable for drinking without adequate pre-treatment. In order to develop a sustainable water supply, different countermeasures are possible. Among them count the increase of efficiency in irrigation (drip systems, precision sprinklers) and in municipal water distribution, use of water non-intensive crops, water re-use and creation of reservoir basins. All these options are related to costs and are limited by their own potential and by other limitations (e.g. time required for the realization of these measures, maximum growth rates of efficiency improvements and renewable energy technologies, political issues related to partial replacement of irrigation water by "virtual water”, i.e. food import). If the mentioned measures are not sufficient to satisfy the water demand, non-conventional water sources like seawater desalination are used. Such plants already exist in the MENA countries: in fact the region leads the world in the use of desalinated water (over $60 \%$ of the world desalination capacity). In the region sixteen countries out of 21 already face water stress. With ever increasing 
population and industrialization of the region's economy, water stress is expected to increase. Furthermore, projections of climate change impacts on the region's water availability are by trend unfavorable, with local decreases of up to $40 \%$ projected for some countries by the end of the 21st century [1]. Unconventional methods for the production of drinking water like desalination will therefore play an even more important role. However, despite desalination plants contributing to reduce the problem of water scarcity, they are characterized by high specific energy consumption and environmental impacts like greenhouse gas emissions, entrainment of marine organisms in the water intake and the presence of chemicals in the brine. Therefore new desalination capacities should be built only if environmental impacts are minimized.

\section{Desalination technologies}

As this work focuses on utility scale desalination plants, two technologies in particular have been considered: reverse osmosis (RO) and multiple effect distillation (MED). A third technology -multi-stage flash (MSF)- was excluded from the current analysis due to its high investment cost, elevated power requirements (around 3-times higher than MED) and high cooling water needs. It should be mentioned however that MSF has been for several decades "the" desalination technology in the Gulf Countries due to its simplicity of operation, reliability and long operation experience. RO offers several advantages in comparison to thermal desalination technologies. Nevertheless, RO has some weak points, in particular the high dependency on the effectiveness of pre-treatment. Better product water quality can be provided by 2-stage systems, where the product water from the first stage is used as feed water for the second stage. Thermal desalination technologies such as multiple effect distillation (MED) and multi-stage flash (MSF) can treat very saline raw water and produce good distillate quality $(<20 \mathrm{ppm})$. They are also highly reliable with long running periods between cleaning (6 - 24 months). MED has better thermal efficiency and relatively low electrical power consumption (ca. $1.5 \mathrm{kWh} / \mathrm{m}^{3}$ ) than MSF systems. All desalination processes use a considerable amount of energy: Table 1 indicates the heat and power requirements for the main desalination technologies discussed above. Note that the electricity consumption of RO units depends on water salinity and quality, while thermal systems can treat low feed water quality without sensible energy consumption variations. The total energy requirements are significantly higher for MSF and MED with thermal vapor compression (TVC) than for $\mathrm{RO}$ and MED. This is due to the heat (steam) requirements for thermal desalination. In co-generation plants, the extracted steam for desalination could be used as an alternative to further electricity production, and therefore can be seen also as a power loss. MED has considerable lower equivalent power loss because the pressure of the extracted steam is lower than in MSF and MED-TVC.

Table 1: Energy requirements of different desalination technologies [2]

\begin{tabular}{lccccc}
\hline Technology & $\begin{array}{c}\text { Spec. el. } \\
\text { Consumption }\end{array}$ & $\begin{array}{c}\text { Steam } \\
\text { pressure }\end{array}$ & $\begin{array}{c}\text { Thermal } \\
\text { energy }\end{array}$ & $\begin{array}{c}\text { Equivalent } \\
\text { power loss }\end{array}$ & $\begin{array}{c}\text { Total energy } \\
\text { requirements }\end{array}$ \\
\hline & $\mathrm{kWh}_{\mathrm{el}} / \mathrm{m}^{3}$ & $\mathrm{bar}$ & $\mathrm{kWh}_{\mathrm{th}} / \mathrm{m}^{3}$ & $\mathrm{kWh}_{\mathrm{el}} / \mathrm{m}^{3}$ & $\mathrm{kWh}_{\mathrm{el}} / \mathrm{m}^{3}$ \\
\hline SWRO (Med. Sea) & 3.5 & - & 0 & 0 & 3.5 \\
\hline SWRO (Gulf) & 4.5 & - & 0 & 0 & 4.5 \\
\hline MSF & $4-5$ & $2.2-2.5$ & 80 & $10-20$ & $14-25$ \\
\hline MED-TVC & $1-1.5$ & $2.2-2.5$ & 80 & $10-20$ & $11-21.5$ \\
\hline MED & $1-1.5$ & $0.35-0.5$ & 70 & 3 & $4-4.5$ \\
\hline
\end{tabular}


The choice of one desalination technology depends on a series of considerations: product water price, feed water quality, product water quality, availability of low-cost steam (or heat), expected lifetime, maintenance costs, location-specific issues (e.g. availability of space, pumping requirements, etc.) and has to be evaluated case-by-case. An important role is also played by historic experience with different desalination techniques and aversion to risk of local water agencies.

\section{RENEWABLE ENERGY FOR DESALINATION: WHY CSP?}

An obvious characteristic of most water scarce areas is that they typically are sunny regions. From there comes the idea to use solar energy to reduce the problem of water scarcity. In the past decades several technologies and concepts have been developed to transform solar irradiation into heat and electricity. In particular CSP -with the option of thermal storage and hybridization- allows a flexible operation of power and desalination plants. The principle of operation of a concentrating solar collector and of a CSP plant is drafted in Figure 1, showing the option of combined generation of heat and power, whereas electricity generation alone is obviously also possible.
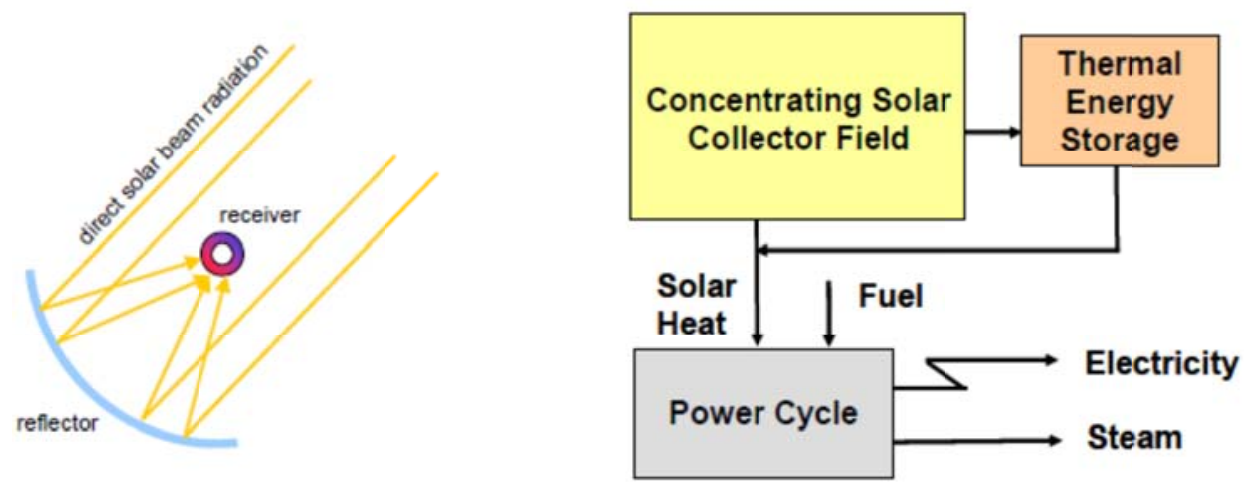

Figure 1. Scheme of a parabolic trough (left) and basic components of a CSP plant (right)

Concentrating solar thermal power is a renewable energy technology which allows converting solar irradiation into high temperature heat and -in a successive step- into electricity. The core element is a mirror field which reflects direct normal irradiance (DNI) to a focus line or point, called receiver. Depending on the adopted technology, temperatures between $400{ }^{\circ} \mathrm{C}$ and $1,000{ }^{\circ} \mathrm{C}$ can be achieved. These plants allow providing dispatchable power, i.e. power capacity on demand, because they make use of conventional steam cycles, in which hybrid operation with fossil fuel is possible. In this sense solar energy can be seen as an effective fuel saver within a conventional power plant. Furthermore, the key advantage of CSP in comparison to other renewable energy technologies like PV and wind is that the fossil fuel consumption can be further reduced by over-sizing the collector field and storing a share of the heat in a thermal energy storage system. This surplus energy can be used during evening or night times and to compensate short-time solar irradiation fluctuations. Solar operation round-the-clock is also possible. From the point of view of a grid operator, CSP with thermal energy storage and/or additional back-up co-firing just behaves like any conventional fuel fired power station, but with considerably less fuel consumption. These characteristics make CSP eligible for grid stability and control purposes in electricity supply systems with high shares of renewable energy sources. CSP plants can be designed from $5 \mathrm{MW}$ to several 
$100 \mathrm{MW}$ of capacity. Another major advantage of CSP stations is the fact that the steam turbines used for power generation provide an excellent spinning reserve (i.e. unused capacity which can be activated for short time compensation of any failures or outages within the electricity grid in accordance with the requirements of the system operator. Spinning reserve can only be provided by rotating machines like steam or gas turbines). Moreover, the design of CSP plants can be adapted to the demand and to the load segments (base-, intermediate- or peak load), as required by grid operators. The mentioned features make CSP an excellent choice for coupling with desalination, which works preferably at constant load, even if part load operation is technically possible. This feature is important primarily for thermal systems, while RO can benefit from the fact that it uses only electricity, which can be also provided by the electricity grid. In the following, the main CSP technologies are briefly described and compared.

\section{CSP Technologies}

CSP can be classified in line-focusing and point-focusing systems. Line-focusing systems include Parabolic Trough (PT) and Linear Fresnel Reflectors (LFR). Line focusing systems are designed in rows (several hundred meters long), typically oriented in the north-south direction. These systems have a one-axis tracking system and track the sun in the east-west direction. Linear Fresnel systems have been developed with the aim to achieve a more simple design, achieving lower cost than parabolic troughs. Point-focusing systems include Central Receiver (Tower) and Dishes. Due to their geometry, point focusing systems have to track the sun on both axes. Tower systems are mainly large-scale power plants with a typical optical concentration factor which ranges from 200 to 1,000. In Dishes mirrors are located on the surface of a 3-D paraboloid. Dishes are typically coupled with a Stirling engine in a Dish-Stirling System, whereas a steam engine can also be used. Dishes vary widely in size from micro dishes with diameters of a few centimeters to large dishes with diameters of over 10 meters. In principle, all CSP technologies can be used for generating electricity and heat. All are suited to be combined with membrane as well as with thermal desalination systems. However, in this work a pre-selection has been carried out to find a CSP technology that can be used as reference with respect to performance, cost and integration with utility scale seawater desalination plants (reference capacity of $100,000 \mathrm{~m}^{3} / \mathrm{d}$ ). High importance has been given to the state of development of all relevant components of the respective CSP technology. An overview of the features of the CSP technologies as well as main advantages and drawbacks is given in Table 2. Based on the considerations exposed, the parabolic trough with synthetic oil as heat transfer medium has been selected as the CSP reference technology for further analysis. Parabolic trough power plants represent about $88 \%$ of the worldwide installed CSP capacity and about $97.5 \%$ of all capacity which is currently under construction [3]. These values show that the parabolic trough -with or without thermal energy storage ( 2 molten salt tanks)- is "the" actual choice of project developers. This does not exclude any other CSP technology from being considered, assessed or used (e.g. direct steam generation with Linear Fresnel, Tower for high temperature applications) in combination with seawater desalination, as soon as the considered technology is assessed as proven, mature, and reliable. 
Table 2: CSP technology comparison [1]

\begin{tabular}{|c|c|c|c|c|}
\hline Technology & Parabolic Trough & Linear Fresnel & Solar Tower & $\begin{array}{l}\text { Dish Stirling } \\
\text { Engine }\end{array}$ \\
\hline $\begin{array}{l}\text { Capacity } \\
\text { [MW] }\end{array}$ & $10-250$ & $5-250$ & $10-100$ & $0.01-1$ \\
\hline $\begin{array}{l}\text { Capacity installed } \\
\text { [MW] }\end{array}$ & $\begin{array}{l}920 \text { (1600 under } \\
\text { construction) }\end{array}$ & $\begin{array}{l}7 \text { (40 under } \\
\text { construction) }\end{array}$ & $\begin{array}{l}38 \text { (17 under } \\
\text { construction) }\end{array}$ & Several prototypes \\
\hline $\begin{array}{l}\text { Annual solar } \\
\text { efficiency }\end{array}$ & $10-16 \%$ & $8-12 \%$ & $10-16 \%$ & $16-29 \%$ \\
\hline $\begin{array}{l}\text { Concentration } \\
\text { Ratio }\end{array}$ & $50-90$ & $35-170$ & $600-1.000$ & $<3.000$ \\
\hline Land Use Factor & $25-40 \%$ & $60-80 \%$ & $20-25 \%$ & $20-25 \%$ \\
\hline $\begin{array}{l}\text { Estimated } \\
\text { investment } \\
{[€ / \mathbf{k W}]}\end{array}$ & $3,500-6,500$ & $2,500-4,500$ & $4,000-6,000$ & $\begin{array}{l}6,000-10,000 \\
\text { (SM1 only) }\end{array}$ \\
\hline $\begin{array}{l}\text { Development } \\
\text { Status }\end{array}$ & $\begin{array}{c}\text { Commercially } \\
\text { proven }\end{array}$ & $\begin{array}{c}\text { Recently } \\
\text { commercial }\end{array}$ & Semi-commercial & Prototype testing \\
\hline Advantages & $\begin{array}{l}\text { Long-term proven } \\
\text { reliability and } \\
\text { durability; } \\
\text { Storage options for } \\
\text { oil-cooled trough } \\
\text { available }\end{array}$ & $\begin{array}{c}\text { Simple structure } \\
\text { and easy field } \\
\text { construction; } \\
\text { Tolerance for slight } \\
\text { slopes; } \\
\text { Direct steam } \\
\text { generation proven }\end{array}$ & $\begin{array}{l}\text { High efficiency of } \\
\text { power cycle; } \\
\text { Tolerance for } \\
\text { non-flat sites; } \\
\text { Option of powering } \\
\text { gas turbines and } \\
\text { combined cycles }\end{array}$ & $\begin{array}{l}\text { High efficiency of } \\
\text { power cycle; } \\
\text { Independent from } \\
\text { land slope; } \\
\text { High modularity }\end{array}$ \\
\hline Disadvantages & $\begin{array}{c}\text { Limited HTF } \\
\text { temperature; } \\
\text { complex structure; } \\
\text { High precision } \\
\text { required; } \\
\text { Flat land required }\end{array}$ & $\begin{array}{l}\text { Storage for direct } \\
\text { steam generation } \\
\text { (Phase Change } \\
\text { Material) still in } \\
\text { R\&D stage }\end{array}$ & $\begin{array}{l}\text { High maintenance } \\
\text { and equipment costs }\end{array}$ & $\begin{array}{c}\text { Not commercially } \\
\text { proven; } \\
\text { High complexity } \\
\text { compared to } \\
\text { stand-alone PV; } \\
\text { No storage available }\end{array}$ \\
\hline
\end{tabular}

\section{GLOBAL POTENTIAL OF CSP AND DESALINATION IN MENA}

\section{Applied Methodology}

After the reference plant capacity has been defined and suitable CSP and desalination technologies have been selected, the presented work firstly focuses on the potential assessment, which consists of the calculation of the solar resource potential as well as the exclusion of areas that for various reasons would be ill-suited for the development of a CSP-desalination plant. In the next step a basic engineering of the reference plants has been carried out in order to characterize the processes from a techno-economic point of view. This analysis is completed by the calculation of per-unit specific production costs for water and electricity for a number of defined cases. Finally, these results are fed into the water supply scenario for MENA, where the structure and main findings are presented and discussed. The paper concludes by addressing general financial as well as environment issues of CSP-desalination projects. For the sake of brevity this paper will not present all results which have been generated during the study. The focus is rather given to selected topics; however, a complete and detailed description of the assumptions, methodologies and results can be found in [1].

\section{DNI Potential}

For the assessment, design and control of CSP systems high resolution irradiation data are needed. The DNI serves as reference for those systems. Contrary to the diffuse 
share, this beam irradiance can be focused in order to yield higher energy flux densities at the receiver. The German Aerospace Center (DLR) has developed a method that models the irradiation through the atmosphere to calculate the DNI on the ground at any time and any site, by detecting and quantifying those atmospheric components that absorb or reflect sunlight, like clouds, aerosols, water vapor, ozone, gases etc. [4] via remote sensing satellites. Hourly DNI data of at least 10-15 years should be analyzed to obtain reliable data for project development. However, for potential assessment one year data is considered sufficient. The analyzed DNI data refer to the year 2002.

\section{Land Exclusion Criteria}

Of course, not all areas with sufficient technical or economical DNI potential are well-suited for the development of CSP projects. Thus, the next phase of the analysis is the detection of land resources which allow the construction of CSP plants. This is achieved by excluding all land areas that are unsuitable for the erection of solar fields:

- $\quad$ Terrain slope $>2.1 \%$ / Shifting sands and dunes

- Irrigated cropland / forests / protected areas

- Water bodies / permanently flooded areas

- Urban areas / infrastructure

Geographic features are also derived from remote sensing data and stored in a geographic information system (GIS). Finally, those data sets are combined to yield a set of exclusion criteria for a complete region or country.

\section{CSP and Desalination: Technologies and Potential}

After applying all exclusion criteria derived from the utilized datasets, the resulting data has been processed further in the GIS software. The typical CSP plant that has been selected as reference is a $90 \mathrm{MW}$ net parabolic trough power plant with a Solar Multiple of 2, which corresponds to a 7.5 hours full load storage operation. Such plants have a size of about $4 \mathrm{~km}^{2}$. Thus, all areas which are in principle suitable for a CSP plant, but smaller than $4 \mathrm{~km}^{2}$ are excluded. Assessing the potential of combined CSP and desalination plants has required some additional processing, because the placement of desalination plants is subject to certain exclusion criteria as well. For example, to avoid high pumping losses and long water intake structures, the desalination plant needs to be sited not over $20 \mathrm{~m}$ above sea level and not more than $5 \mathrm{~km}$ away from shore. Further, it has to be considered that when combining a MED plant with a CSP plant, the solar field and the turbine have to be placed close to the MED. Finally, the data derived from the solar energy- and the land resource assessments were used to generate maps showing the DNI at potentially suitable sites for CSP in MENA (

Figure 2). Those maps were statistically analyzed yielding the CSP (parabolic trough) potential for electricity generation and seawater desalination in each country (Table 4). Solar electricity potentials were calculated from the annual DNI sum considering an average annual efficiency of $15 \%$ and a land use factor of $30 \%$. These values correspond to state of the art parabolic trough power plants. Following work steps within the MENA Water Outlook Project (not described within this paper) have been the selection of potential sites adapted for the construction of combined CSP and desalination plants in collaboration with the Governments in the MENA countries. Other combinations of renewable energies like PV and Wind have also been taken into account and optimized according to the available local resources. Location-specific data have been collected and hourly simulations have been carried out in order to assess the plant yields in more detail. 
Similar pre-feasibility studies have been already carried out by DLR during the MED-CSD project [6].

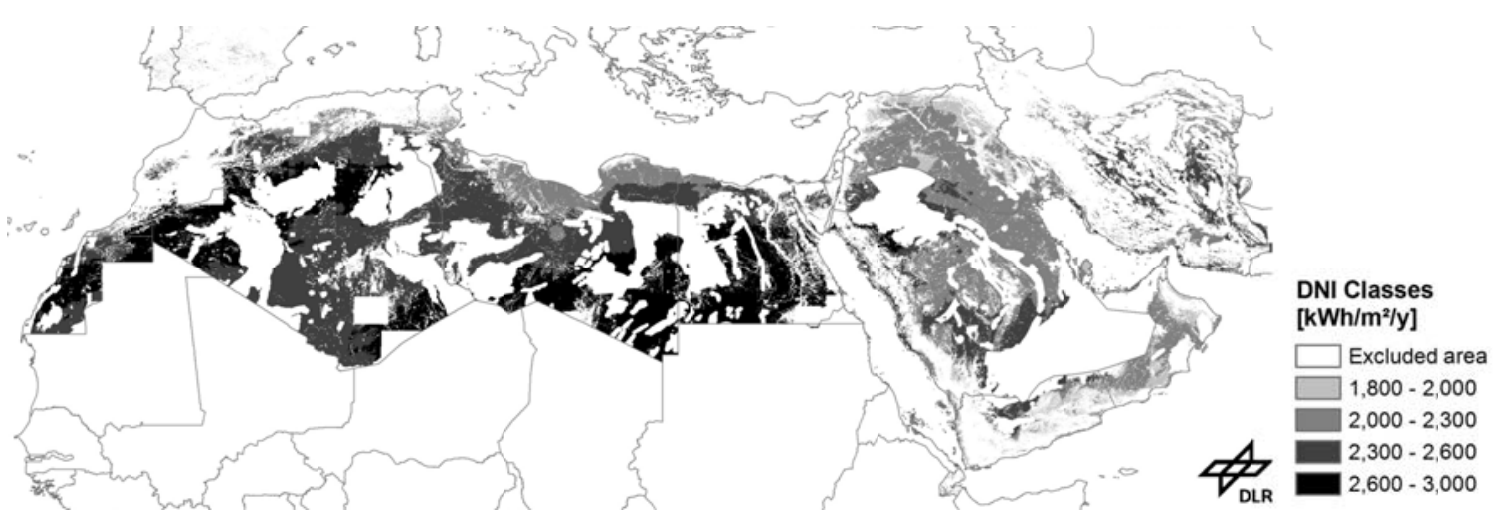

Figure 2: Concentrating Solar Power Potential in the MENA Region [4, 5]

\section{Analyzed Plant Configurations}

The current project phase focuses on the potential assessment of combined CSP and desalination plants for the whole MENA Region. For this reason, a certain degree of generalization is required. Indeed, a set of suitable typical desalination plants are considered. All configurations are designed to be operated at base load (8,000 operation hours/year) under the assumption that -if no energy from solar field and/or storage is available- the gap to the full load is guaranteed by hybrid operation. The thermal energy storage ( 2 molten salt tanks) added to the CSP plant (7.5 hours of nominal operation at design) allows for a dramatic reduction of the fossil share. Four configurations have been analyzed:

1. CSP-MED located at the coast (Figure 3).

2. CSP-RO plant at the coast with once-through cooling located near desalination plant (Figure 4).

3. Decoupled combination of RO at coast and dry cooled CSP plant located inland.

4. RO at the coast with dry cooled CSP plant and solar only operation.

These four cases have been calculated for 2 direct normal irradiation (DNI) classes:

1. medium irradiance: $2,000 \mathrm{kWh} /\left(\mathrm{m}^{2} \mathrm{y}\right)$ on the coast and $2,400 \mathrm{kWh} /\left(\mathrm{m}^{2} \mathrm{y}\right)$ inland

2. excellent irradiance: $2,400 \mathrm{kWh} /\left(\mathrm{m}^{2} \mathrm{y}\right)$ on the coast and $2,800 \mathrm{kWh} /\left(\mathrm{m}^{2} \mathrm{y}\right)$ inland

The configurations are designed in such a way that each configuration produces the same amount of water and electricity (with the exception of case 4). The capacity of the desalination is fixed $\left(100,000 \mathrm{~m}^{3} /\right.$ day $)$. The large size of the desalination plant results from the project requirements, which are the supply of large city centers in the MENA Region. The most relevant energy requirement for desalination is the heat needed for the MED. Out of it the turbine and the solar field can be designed. In the end, a net power production of $90 \mathrm{MW}$ for all considered cases was chosen. Once the turbine satisfies this condition, a large surplus of electricity is generated (Table 3), which can be fed into the grid. 


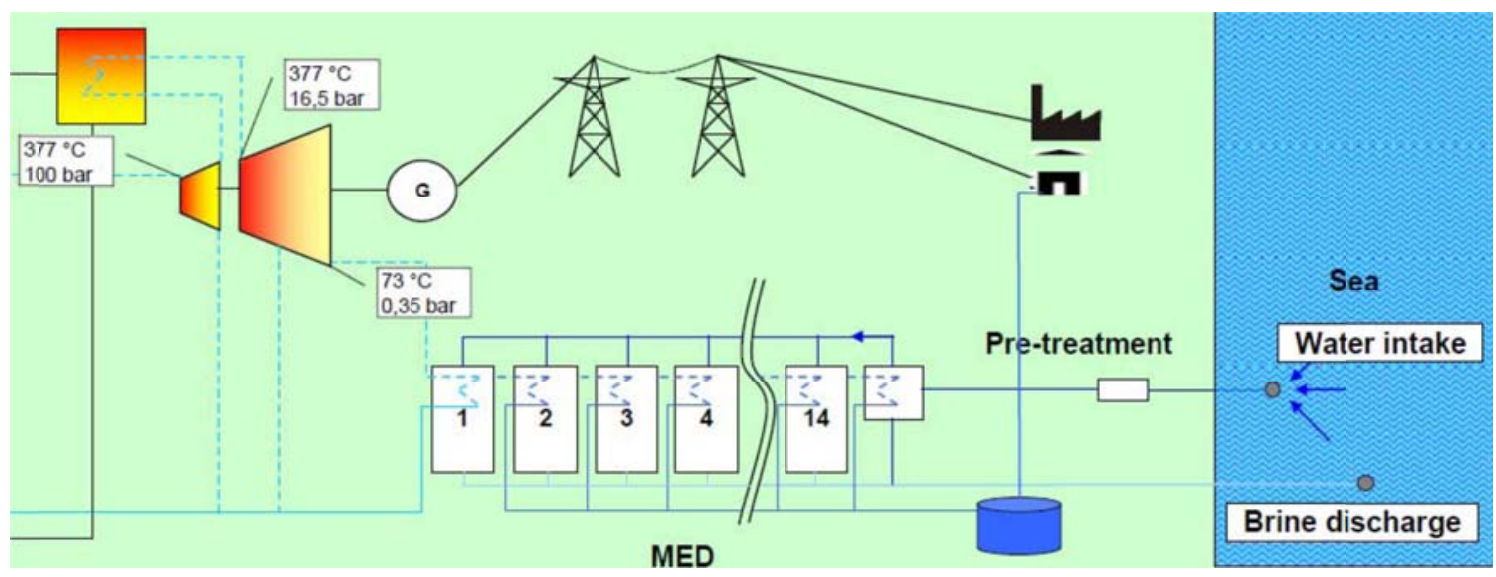

Figure 3: CSP-MED plant scheme

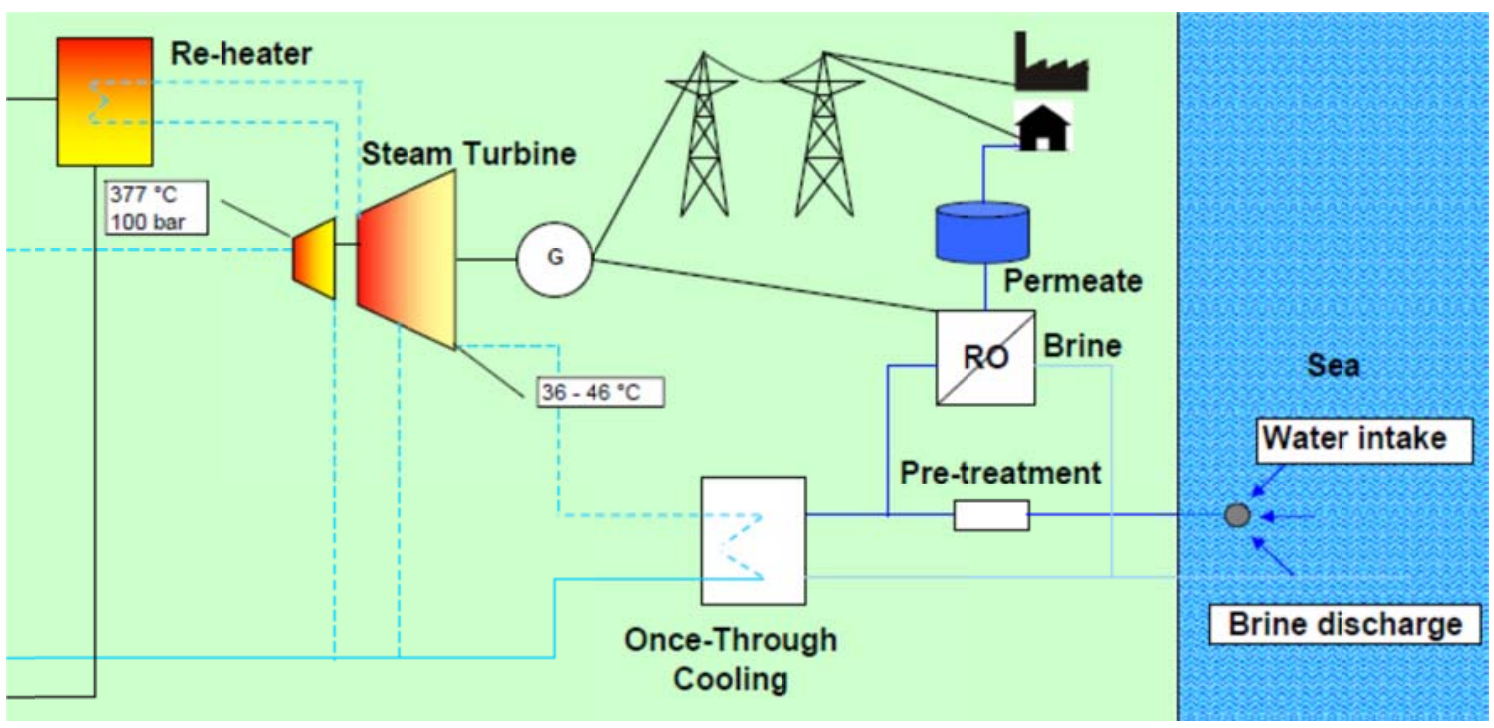

Figure 4: CSP-RO located near to the coast shore

The CSP plant of the RO case is calibrated to have the same net electricity production. Finally, the RO plant can be simply scaled up to the MED water production. The model compares the net -and not the gross- electricity production which differs only by internal energy requirement, also called parasitics, i.e. the internal electricity consumption of the system components (solar field, storage, turbine and desalination). In particular, the specific electricity consumption of SWRO is larger than MED (around 3-times more). However, the negative effect of higher parasitics of RO is more than compensated by better turbine efficiency. The annual solar equivalent full load hours are calculated as function of DNI yearly sum and storage size according to [7]. The water consumption of the CSP plants with wet cooling amounts to ca. 3,800 l/MWh. Around $92 \%$ of the water is consumed in the cooling system, while $6 \%$ is used for the turbine cycle and only $2 \%$ for mirror cleaning (ca. $27 \mathrm{l} / \mathrm{m}^{2} / \mathrm{y}$ ) [8]. Passing from a wet cooling to a dry cooling system allows for saving of ca. $90 \%$ of the water consumption, whereas this water saving is to be considered together with higher electricity generation cost due to the lower electrical efficiency of the turbine. For a more precise evaluation, yearly simulations should be carried out. Local temperature and relative humidity conditions play an important role here. 
Table 3: Results overview for the Arabian Gulf region, good irradiation $\left(2,400-2,800 \mathrm{kWh} / \mathrm{m}^{2} / \mathrm{y}\right.$ and Natural Gas (NG) as back-up fuel)

\begin{tabular}{|c|c|c|c|c|c|}
\hline & Unit & MED/CSP & $\begin{array}{c}\text { RO/CSP + } \\
\text { Once-Throug } \\
\text { h Cooling }\end{array}$ & $\begin{array}{c}\text { RO/CSP } \\
\text { + Dry } \\
\text { Cooling }\end{array}$ & $\begin{array}{c}\text { RO/CSP + } \\
\text { Dry Cool. + } \\
\text { Solar Only }\end{array}$ \\
\hline Location: Arabian Gulf & - & \multicolumn{2}{|c|}{ Coast } & \multicolumn{2}{|c|}{ Inland } \\
\hline$\overline{\text { DNI }}$ & $\begin{array}{c}\mathrm{kWh} /\left(\mathrm{m}^{2}\right. \\
\text { year })\end{array}$ & \multicolumn{2}{|c|}{2,400} & \multicolumn{2}{|c|}{2,800} \\
\hline Solar Multiple & - & \multicolumn{4}{|c|}{2} \\
\hline Seawater Design Temp. & ${ }^{\circ} \mathrm{C}$ & \multicolumn{4}{|c|}{35} \\
\hline Seawater Design Salinity & ppm & \multicolumn{4}{|c|}{46,000} \\
\hline Desalination Capacity & $\mathrm{m}^{3} /$ day & \multicolumn{4}{|c|}{100,000} \\
\hline Fossil Fuel & - & \multicolumn{4}{|c|}{ Natural Gas } \\
\hline Turbine Efficiency & $\%$ & 32.9 & 37.0 & \multicolumn{2}{|c|}{35.0} \\
\hline Gross Power Production & MW & 107.8 & 120.0 & \multicolumn{2}{|c|}{120.4} \\
\hline Net Power Production & MW & 90.0 & 90.0 & \multicolumn{2}{|c|}{90.0} \\
\hline $\begin{array}{l}\text { Internal El. } \\
\text { Consumption }\end{array}$ & MW & 17.8 & 30.0 & \multicolumn{2}{|c|}{30.4} \\
\hline Thermal flow solar field & MW & 654 & 648 & \multicolumn{2}{|c|}{688} \\
\hline Mirror area & $\mathrm{km}^{2}$ & 1.26 & 1.25 & \multicolumn{2}{|c|}{1.32} \\
\hline Required Land Area & $\mathrm{km}^{2}$ & 4.78 & 4.73 & \multicolumn{2}{|c|}{5.03} \\
\hline Energy storage Capacity & MWh & 2,504 & 2,479 & \multicolumn{2}{|c|}{2,634} \\
\hline Solar Full Load Hours & $\mathrm{h} /$ year & \multicolumn{2}{|c|}{3,652} & \multicolumn{2}{|c|}{4,344} \\
\hline Total Full Load Hours & h/year & \multicolumn{3}{|c|}{8,000} & 4,344 \\
\hline Solar Share & $\%$ & & $5.7 \%$ & $54.3 \%$ & $100.0 \%$ \\
\hline Total Net Power Prod. & $\mathrm{GWh}_{\mathrm{e}} /$ year & \multicolumn{3}{|c|}{719.8} & 390.8 \\
\hline Total Water Production & Mio. $\mathrm{m}^{3} /$ year & \multicolumn{4}{|c|}{33.3} \\
\hline
\end{tabular}

\section{Electricity Production Cost}

The cost assessment aims at the estimation of the levelized electricity cost (LEC). The LEC is defined as the per-unit price at which electricity should be generated from a certain power plant in order to break even over the project lifetime. This assessment is based on the capital expenditure (CAPEX) and operational expenditure (OPEX). The LEC included in the report are indicative and highlight the ranking between different configurations. The CAPEX include mechanical and electrical equipment, civil works, auxiliary systems, development cost, engineering and project management. Cost of land, interest charges under construction and import taxes are not considered. A detailed overview of cost assessment methodology and investment assumptions can be found in [1, chapter 6]. The OPEX include annual capital cost, costs for fuel, personnel, operation and maintenance, mirror and absorber replacement, and insurance. For the calculation, a plant life of 25 years and a discount rate of $6.0 \%$ are assumed. Operation and Maintenance cost is assumed to be $2.0 \%$ /year of the total investment, while insurance accounts to $0.5 \%$ /year of total CAPEX [7]. Cost of steam for the MED is calculated according to reference cycle method [2]. In this method, the energy associated with the steam extracted to the thermal desalination plant is considered in terms of loss of electric 
power that would otherwise be used for further electricity generation. As back-up fuels heavy fuel oil and natural gas have been considered. The price for the back-up fuel has been derived from the crude oil price by means of fuel factors. A fuel factor of 1.0 would mean that the fuel price is equal to the crude oil price. For natural gas a fossil fuel ratio of 0.8 has been assumed, and for heavy fuel oil, 0.85 [9]. For the crude oil price, 110 US\$/barrel has been assumed. In case 4 the RO is operated solar-only, so electricity from the grid is used. The actual electricity prices of Saudi Arabia (0.041 US\$/kWh [9]) representing Middle East and of Morocco (0.079 US\$/kWh [10]) for the Mediterranean region are implemented in the cost evaluation. The results of Figure 5 show that the CSP-RO with Once-Through cooling system has lower LEC than the equivalent MED/CSP plant. Case 3 presents similar LEC as case 2. In this case the higher DNI in the inland location is compensated by the lower efficiency of the dry-cooling. Again, the influence of the real amount of the mentioned compensation should be analyzed case-by-case. If one assumes high irradiance conditions, the LEC of the cases 3 and 4 is lower than in the two previous cases. Case 4 is more sensitive than other configurations to DNI variations due to the solar-only operation. Indeed, in the last case the number of operation hours is not fixed like in the other 3 cases (8,000 hours/year), but is directly affected by the DNI yearly sum. So, in a location with a relatively low DNI the turbine is operated less hours, less electricity is produced and in the end LEC is higher, while in the other 3 cases electricity is produced by hybrid operation.

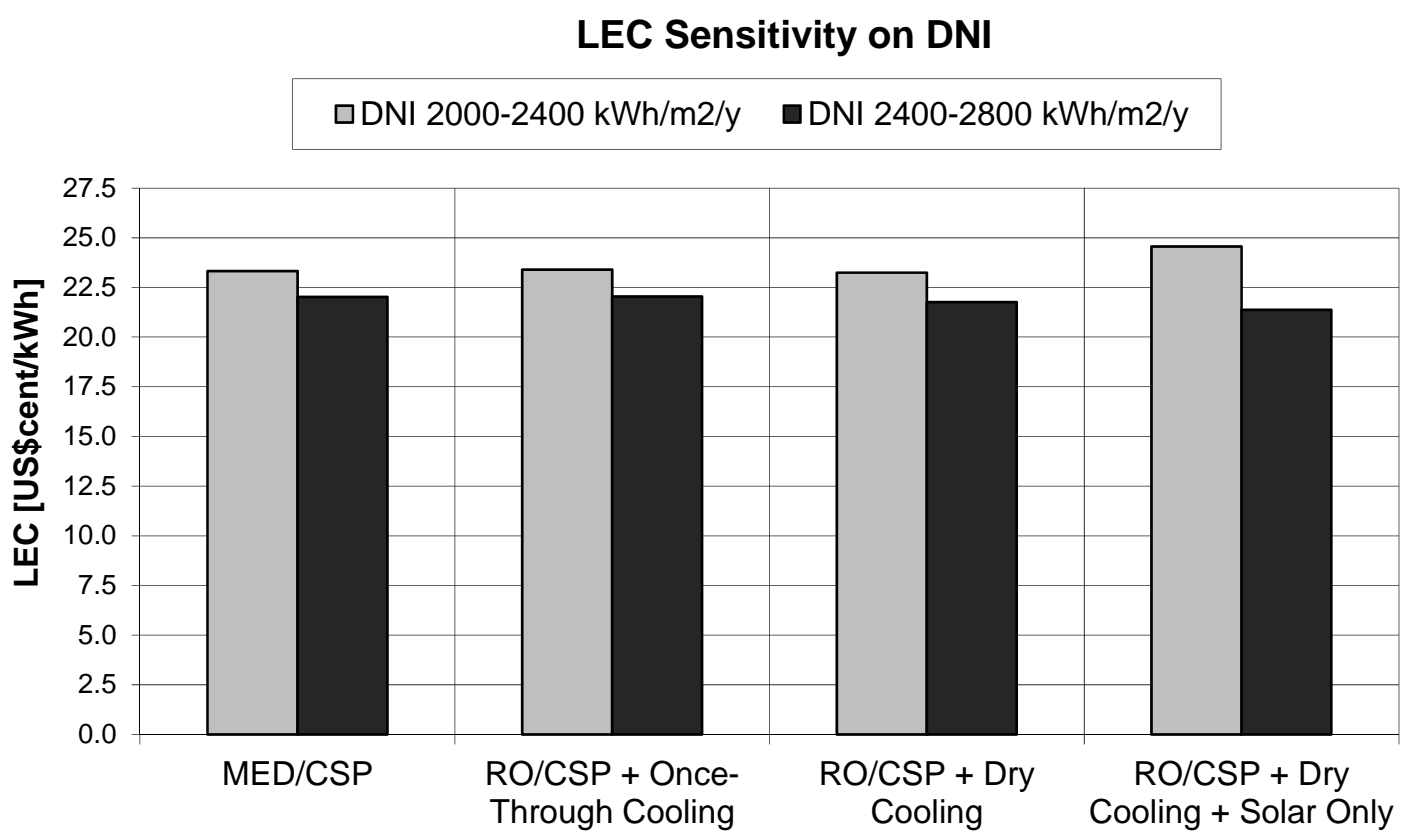

Figure 5: LEC and solar full load hours as function of direct normal irradiation. Assumptions: CSP plant with once-through cooling; Location: Arabian Gulf; Fuel: heavy fuel oil (HFO).

\section{Water Production Cost}

The water production cost (levelized water cost or LWC) are calculated similarly to the electricity cost. Main economic assumptions for the desalination technologies have been provided by [9]. The estimation of the water production costs is based on the calculation of the annual costs that comprise annual capital costs, annual operational costs, costs for power (electricity and in the case of MED also heat), fuel, chemicals, personnel, maintenance, membrane replacement and insurance. The costs do not include 
cost of land and cost of drinking water conveyance facilities outside the plant boundary. A plant availability of $94 \%$ has been assumed. Figure 6 shows that the unit water prices by SWRO in the Mediterranean region are lower the ones in the Red Sea and Arabian Gulf. This is strongly related to the seawater quality differences (salinity and temperature). In the Gulf region the assessed costs are even higher; however it should be kept in mind that the results shown particularly for the plants in the Gulf involve more intensive pre-treatment process compared to Mediterranean and Red Sea region for example. Due to its robust behavior against higher seawater temperature and salinity, MED presents slightly lower LWC in the Arabian Gulf than RO. Nevertheless, in the Mediterranean Sea and Red Sea dual-purpose MED plants would produce water at higher unit prices. The higher LWC of water produced by MED in the Mediterranean Region in comparison to the ones in the Gulf is due to the different heat costs resulting from the reference cycle method. However, under special circumstances (high seawater salinity and temperature, high fluctuations in seawater quality, presence of algae bloom in seawater) MED in its dual-purpose configuration can appear preferable for specific projects. LWC from combined CSP and desalination plants are still higher than LWC from conventional plants. Actual LWC from desalination plants varies within a large range (between ca. 0.4 and $2.5 \mathrm{US} \$ / \mathrm{m}^{3}$ ), whereas the major amount of the plant presents LWC between 0.5 and $1.5 \mathrm{US} \$ / \mathrm{m}^{3}[11]$.

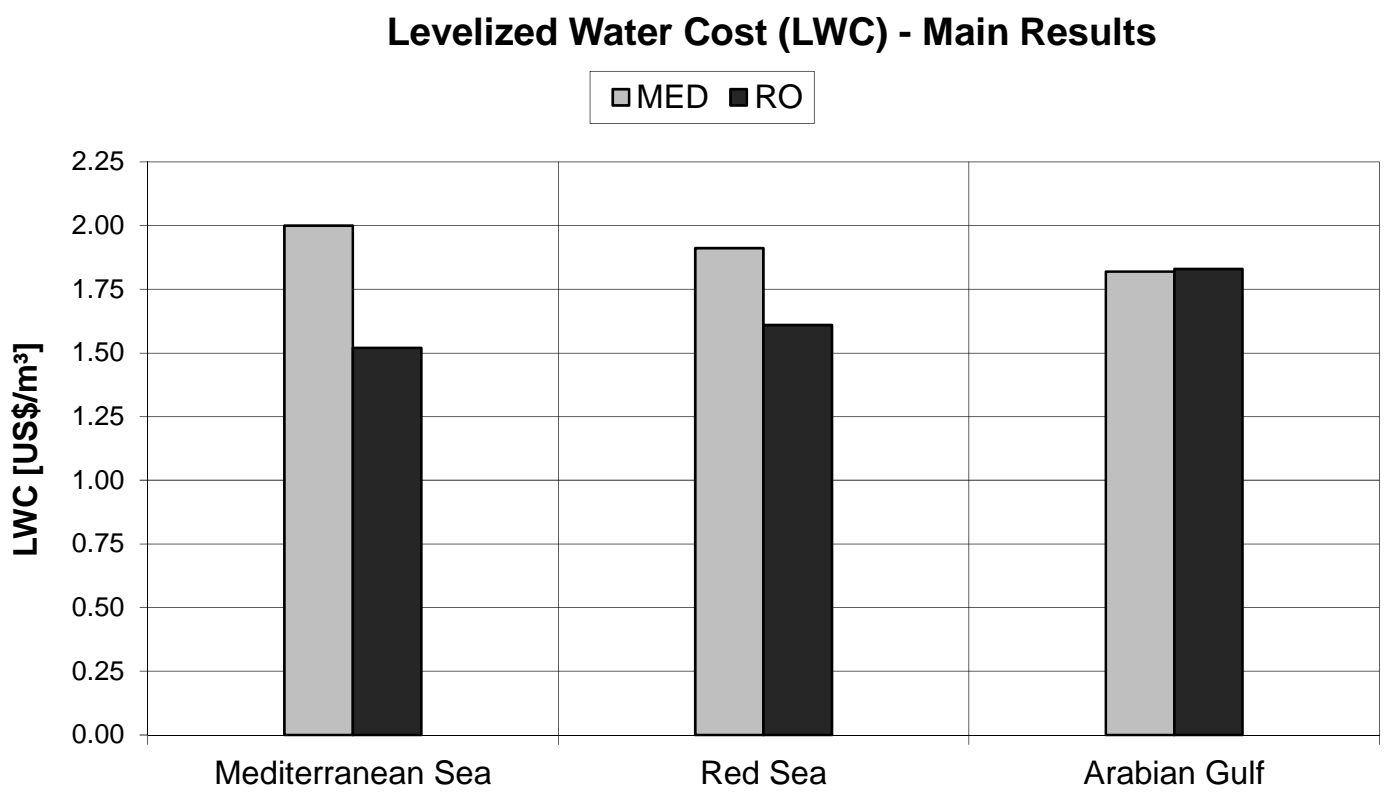

Figure 6: LWC comparison. Assumptions: DNI, good irradiation $\left(2,400-2,800 \mathrm{kWh} / \mathrm{m}^{2} / \mathrm{y}\right)$; back-up: NG)

\section{WATER SUPPLY SCENARIO}

\section{Water Demand Model}

The water demand model was taken from the report of FutureWater [12], which gives a balance of demand for irrigation, urban use and industry and its potential development between the year 2000 and 2050. FutureWater used an advanced distributed hydrological model to determine the renewable water resources including external renewable water resources for the current and future climate. It is important to underline that the water 
demand assessment is carried out on a monthly basis. Many studies assess water stress on an annual scale which underestimates the actual water stress because water demand and supply do not occur necessarily at the same time. This study uses the A1B GHG (i.e. greenhouse gases) emission scenario, which is widely used and recommended by the IPCC. This scenario assumes a world of rapid economic growth, a global population that peaks in mid-century and rapid introduction of new and more efficient technologies. Different global circulation models (GCM) have been analysed. Finally, the average climate change scenario has been selected as reference for the assessment of the water supply. The natural year-by-year variability of temperature, evapotranspiration and precipitation are taken into account by creating a time series with random years [12].

\section{Water Supply Model}

The primary goal of the scenario analysis is to cover the water demand at each time step, while overexploitation of groundwater is substituted by sustainable water sources. The model is based on the methodology developed within the prior study AQUA-CSP [13]. In order to cover the demand, there are several options. Each option is characterized by a degree of priority and is limited by its time-variable potential:

1. Natural water extractions are considered to be a least cost option and thus have highest priority in our scenario. In general, we have given priority to the use of surface water extractions over groundwater extractions. This leads to a saving of groundwater resources in those years when they are not needed, while surface water is used as much as possible.

2. Future efficiency gains play a key role in the future water supply. Urban and industrial water use efficiencies start from the initial value in 2000 and develop with a linear function up to a set value that has to be reached in 2050 [14]. It is assumed that those countries that display rather low efficiency in 2010 will experience a stronger efficiency enhancement than those countries that already have a high efficiency standard today.

3. The treatment and reuse of wastewater was assumed to also have high priority. The assumed goal is to reach $20 \%$ of wastewater reuse from industry and urban applications. In principle, higher shares of wastewater treatment and reuse could be achieved, if policies are adapted accordingly and if economic incentives are strong enough.

4. The existing conventional desalination capacity in each country was derived from the Desaldata database [15]. Planned capacity additions between 2010 and 2015 were added to the capacities in operation in the year 2010 [16]. From the Desaldata database the year of commissioning of each plant can also be obtained. From this information, the expected year of decommissioning can be deduced. Life times of 20 years for RO, 25 years for MED and 35 years for MSF plants were assumed. This results in a subsequent potential reduction of conventional desalination capacity, which in our scenario is replaced by desalination powered by solar energy, a mix of renewable sources or any other available source of energy.

5. Unsustainable extractions of groundwater are only allowed in our model if no other sources are available to cover the demand. Unsustainable extraction could also mean that the demand is not met at all.

6. Due to its high cost, we have considered CSP desalination plants as the last option in our scenario to eliminate unmet water demand that only will be applied after making full use of all other available water sources. In the case of replacing old RO plants with new units, the mix of electricity to power the plants will change, 
whereas new CSP desalination capacities may be installed for growing demand. In the case of replacing thermal desalination plants, this could be done either by installing combined solar power and desalination plants using MED, or replacing thermal desalination by RO.

The results coming from this procedure are shown for the whole MENA Region in

Figure 7. Until 2030, increasing deficits will have to be bridged by conventional desalination and by excessive groundwater withdrawals, hoping that those limited resources will remain available and affordable until then. In the medium term, the re-use of waste-water and fossil fuelled desalination will have equal importance to reduce the increasing over-use of non-renewable groundwater resources. However, this does not imply a preference for fossil fuelled desalination for future projects. On the contrary, the scenario assumes a rather quick expansion of CSP for desalination. In most MENA countries the potential of CSP is not limited by the available solar energy resource, but rather by the possible speed of CSP capacity expansion (starting with zero in the year 2015).

Middle East \& North Africa (MENA)

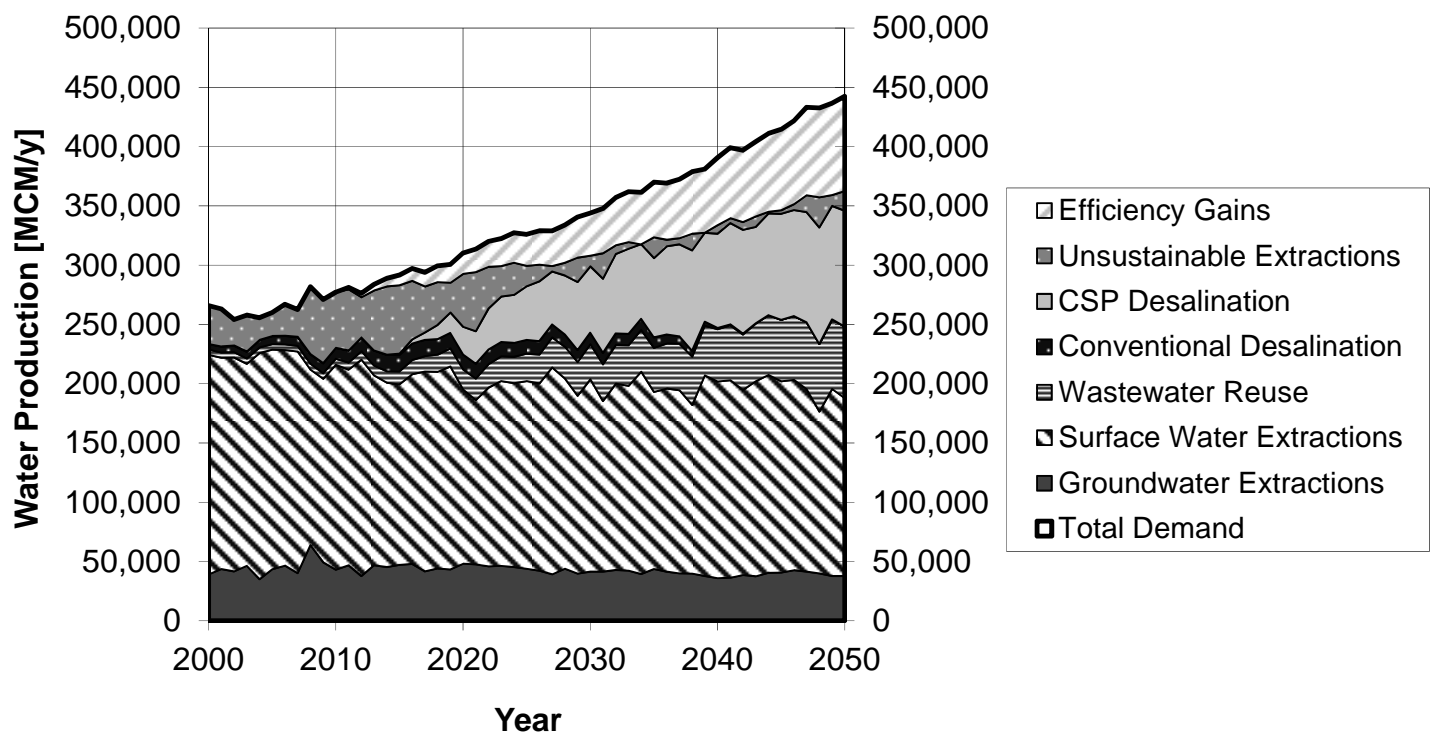

Figure 7: Water Supply Scenario for the MENA Region [1, Data analysis by DLR]

After a phase of market introduction and demonstration that will last about 10-15 years, the most dynamic expansion of CSP for desalination will take place between 2020 and 2030, when CSP will gradually take over large shares of freshwater supply from depleting groundwater resources. In 2050 demand will be mainly covered by natural water (188,000 Mio m³ $/ \mathrm{y}$ ) and by solar powered desalination (98,000 Mio. $\left.\mathrm{m}^{3} / \mathrm{y}\right)$. Table 4 shows that the CSP potential in Malta, Lebanon, Gaza and West Bank will not be sufficient to cover both the growing demand for electricity and the additional energy demand for seawater desalination. Other solutions will have to be found in those four countries. In all other countries, the CSP potential is high enough to cover the future demand for seawater desalination. In most countries it is even possible to cover most of the demand by coastal CSP plants that in principle could produce electricity and desalted 
water in combined generation. The underscored numbers in Table 4 mean that in the considered country there is insufficient CSP desalination potential. In bold are values for countries which can choose RO and MED, because sufficient coastal as well inland CSP potential is available for both technologies. Finally, figures in italic type are for countries which will predominantly use reverse osmosis.

Table 4: Comparison of total CSP potential and CSP potential for desalination

\begin{tabular}{|c|c|c|c|c|c|c|c|c|c|}
\hline & $\begin{array}{c}\text { Total } \\
\text { Water }\end{array}$ & CSP-SWD & $\begin{array}{l}\text { Total } \\
\text { CSP }\end{array}$ & CSP & $\begin{array}{c}\text { Coastal } \\
\text { CSP }\end{array}$ & $\begin{array}{l}\text { RO or } \\
\text { MED }\end{array}$ & Power & RO only & CSP-SWD \\
\hline & $\begin{array}{c}\text { Demand } \\
2050\end{array}$ & $\begin{array}{c}\text { Demand } \\
2050\end{array}$ & Potential & $\begin{array}{c}\text { Demand } \\
2050\end{array}$ & Potential & $\begin{array}{c}\text { Supply } \\
2050\end{array}$ & $\begin{array}{c}\text { Demand } \\
\text { RO }\end{array}$ & $\begin{array}{c}\text { Supply } \\
2050\end{array}$ & $\begin{array}{c}\text { Demand } \\
2050\end{array}$ \\
\hline & $\begin{array}{c}10^{3} \text { Mio. } \\
\mathrm{m}^{3} / \mathrm{y}\end{array}$ & $\begin{array}{c}10^{3} \text { Mio. } \\
\mathrm{m}^{3} / \mathrm{y}\end{array}$ & $\mathrm{TWh} / \mathrm{y}$ & TWh/y & $\mathrm{TWh} / \mathrm{y}$ & $\begin{array}{c}10^{3} \text { Mio. } \\
\mathrm{m}^{3} / \mathrm{y}\end{array}$ & $\mathrm{kWh} / \mathrm{m}^{3}$ & $\begin{array}{c}10^{3} \text { Mio. } \\
\mathrm{m}^{3} / \mathrm{y}\end{array}$ & $\mathrm{TWh} / \mathrm{y}$ \\
\hline Algeria & 13.6 & 2.1 & 135,771 & 120 & 0.0 & 0.0 & 3.5 & 2.1 & 7.5 \\
\hline Bahrain & 0.4 & 0.3 & 16 & 4 & 8.6 & 0.3 & 4.3 & 0.0 & 1.3 \\
\hline Djibouti & 0.1 & 0.0 & 300 & 1 & 0.0 & 0.0 & 4.3 & 0.0 & 0.0 \\
\hline Egypt & 92.6 & 6.7 & 57,140 & 395 & 73.9 & 6.7 & 3.8 & 0.0 & 25.5 \\
\hline$\overline{\text { Gaza }}$ & 0.6 & 0.4 & $\underline{0}$ & $\underline{0}$ & 0.0 & $\underline{0.0}$ & 3.5 & $\underline{0.0}$ & $\underline{1.5}$ \\
\hline Iran & 114.9 & 10.6 & 32,134 & 290 & 267.4 & 10.6 & 3.5 & 0.0 & 37.0 \\
\hline Iraq & 74.2 & 13.3 & 24,657 & 180 & 0.0 & 0.0 & 4.3 & 13.3 & 57.1 \\
\hline Israel & 6.4 & 4.4 & 151 & 29 & 1.7 & 0.4 & 3.5 & 4.0 & 15.4 \\
\hline $\begin{array}{l}\text { Jordan } \\
\text {. }\end{array}$ & 2.5 & 1.5 & 5,884 & 38 & 0.0 & 0.0 & 3.8 & 1.5 & 5.7 \\
\hline$\overline{\text { Kuwait }}$ & 1.3 & 0.7 & 1,372 & 13 & 17.6 & 0.7 & 4.3 & 0.0 & 2.9 \\
\hline Lebanon & 1.9 & 0.3 & $\underline{5}$ & $\underline{5}$ & 0.0 & $\underline{0.0}$ & 3.5 & $\underline{0.1}$ & 1.2 \\
\hline Libya & 6.2 & 2.8 & 82,714 & 25 & 132.3 & 2.8 & 3.5 & 0.0 & 9.9 \\
\hline Malta & 0.2 & 0.1 & 0 & 0 & 0.0 & $\underline{0.0}$ & 3.5 & $\underline{0.0}$ & $\underline{0.3}$ \\
\hline Morocco & 26.1 & 8.5 & 8,428 & 110 & 14.8 & 3.3 & 3.5 & 5.3 & 29.9 \\
\hline Oman & 3.1 & 2.0 & 14,174 & 14 & 83.5 & 2.0 & 3.5 & 0.0 & 7.1 \\
\hline$\overline{\text { Qatar }}$ & 0.6 & 0.4 & 555 & 8 & 43.2 & 0.4 & 4.3 & 0.0 & 1.8 \\
\hline $\begin{array}{l}\text { Saudi } \\
\text { Arabia }\end{array}$ & 37.2 & 23.7 & 75,832 & 135 & 152.4 & 23.7 & 4.3 & 0.0 & 101.7 \\
\hline Syria & 25.3 & 0.9 & 8,449 & 117 & 0.5 & 0.1 & 3.5 & 0.8 & 3.1 \\
\hline Tunisia & 6.5 & 2.6 & 5,673 & 34 & 48.7 & 2.6 & 3.5 & 0.0 & 9.2 \\
\hline$\overline{\text { UAE }}$ & 3.3 & 2.4 & 447 & 40 & 14.9 & 2.4 & 4.3 & 0.0 & 10.3 \\
\hline $\begin{array}{l}\text { West } \\
\text { Bank }\end{array}$ & 1.2 & 0.8 & $\underline{8}$ & $\underline{8}$ & 0.0 & $\underline{0.0}$ & 3.0 & $\underline{0.0}$ & 2.3 \\
\hline Yemen & 24.2 & 13.1 & 8,486 & 65 & 104.0 & 13.1 & 3.8 & 0.0 & 49.7 \\
\hline Total & 442.4 & 97.7 & 462,196 & 1,630 & 963.7 & 69.0 & & 27.1 & 380.4 \\
\hline
\end{tabular}




\section{CONCLUSIONS AND POLICY RECOMMENDATIONS}

\section{Financial Issues}

Like any other country, countries in the Middle East and North Africa need a sustainable water supply structure. In order to set this course, priority will be given to efficiency improvements in the use of water, reuse of treated wastewater and the use of renewable energy, mainly solar energy from concentrating solar power plants, for seawater desalination. CSP is a cost stabilizing element in the future electricity mix and can be seen as a prevention measure against fuel shortage and cost escalation. However, the market introduction of CSP in MENA is characterized by several initial barriers which must be overcome (Table 5). In CSP, the investment for the power block is comparable to that of any conventional power station, but adding solar field and storage means adding considerable investment. One could say that a CSP plant is nothing but a conventional power plant, but the amount of fuel usually burned during the total lifetime of the plant is bought on the first day and placed beside the power block in form of a solar collector field. Fuel is replaced by capital investment. The main problem is that capital investment will require debt service and interest rates that will generate additional costs of finance and insurance that are usually not required for fuel.

Table 5: Major initial barriers for introduction of CSP in MENA [17]

\begin{tabular}{ll}
\hline \multicolumn{1}{c}{ CSP Introduction Barrier } & \multicolumn{1}{c}{ Problem outline } \\
\hline $\begin{array}{l}\text { High initial investment / } \\
\text { High LEC compared to } \\
\text { present average market } \\
\text { prices }\end{array}$ & $\begin{array}{l}\text { CSP is compared with average cost of electricity of the existing power } \\
\text { with high fuel costs is not taken into account. High LEC is due to high } \\
\text { initial investment costs (the amount of fuel usually burned during the total } \\
\text { lifetime of a conventional power plant is represented in CSP by the initial } \\
\text { investment for the solar field). }\end{array}$ \\
\hline $\begin{array}{l}\text { Fuel price volatility } \\
\text { Electricity price volatility hen fuel prices (e.g. in 2008) would have justified implementation } \\
\text { ond unknown revenues }\end{array}$ & $\begin{array}{l}\text { CSP projects have high fixed costs but unknown revenues at open } \\
\text { other renewable energies because decision makers "hope for better days”. }\end{array}$ \\
\hline
\end{tabular}

Replacing fuel by capital goods is in principle favourable for a national economy, as this creates jobs and industrial activities. However, the large investment involved is a major challenge of finance. The main problem for renewable energy producers is that they cannot really calculate their future revenues in open markets. In Germany, a feed-in law protects renewable energy producers, guaranteeing their feed-in tariff at any time, but this is not a sustainable situation and will most probably change in the near future. A renewable energy act like in Germany, opening the power sector to an unlimited expansion of (mainly) fluctuating renewable electricity sources, is not a viable solution for developing countries. This is not a general objection against a feed-in tariff system, but it shows that a tariff system for MENA must be designed in a way that is consistent with the specific demand for capacity additions according to national electricity needs and policy. Looking at the challenges listed in Table 5, the requirements for a successful market implementation of CSP become clear: the associated large long-term investments require equivalent long-term, secure revenues. An investor cannot take the risk of investing in a huge "stock of fuel" for 40 years of operation in the form of a solar collector field, if he is unsure of the stability of a project's revenue streams [17]. One method that can be used to overcome this barrier is a long-term power purchase agreement (PPA) that covers the investment, financing cost, insurance, personnel and 
operation cost of the CSP plants while allowing for a reasonable return for investors. In most cases in MENA, the buyer of electricity will be a public national power utility, while the project structure can be public, private or mixed finance with a BOO (Build, Own, Operate), BOOT (Build, Own, Operate, Transfer), corporate finance or other structure. If private investment shall be stimulated, a long-term purchase agreement must provide a tariff for power and water that covers the full cost of capital and operation plus reasonable revenues for investors. Such tariffs are usually higher than the average tariffs for power and water existing at present. However, they are guaranteed to remain constant and can be reduced once the loan is paid back. Finally, interest rates are the higher, the higher the risk of investment is, while the largest part of the cost of a CSP plant is the cost of capital. Therefore, strong measures must be taken to reduce investment risks, like international guarantees, policy support, transparent public administration and licensing, transparent and foreseeable tariff systems. If risks are minimized, interest rates are minimized and thus, LEC is reduced. In this sense, short- or mid-term higher tariffs for power and water can lead to long-term lower cost of market introduction, if tariffs are harmonized with loan periods.

\section{Environmental Aspects}

Although desalination of seawater offers a constant supply of high quality drinking water -without depleting natural freshwater resources-, there are negative impacts which have to be considered. Conventional desalination plants comprise a tunnel intake, a screening unit, a series of evaporators by thermal systems or membrane units by RO, a post-treatment and a discharge of brine into the sea. Such systems present high carbon dioxide emissions, due to the large amount of fossil fuels for plant construction and operation. The brine contains environmental hazardous chemical additives (Chlorine, Coagulants, Antiscalants, Heavy metals, and Cleaning chemicals) that are required to protect the desalination units from certain seawater constituents. In order to avoid an unruly and unsustainable development of coastal areas, desalination activity should be integrated into management plans that regulate the use of water resources and desalination technology on a regional scale, as well as the evaluation of each single desalination project starting from the planning phase. A standard environment impact assessment (EIA) procedure for evaluating and minimizing the effects of desalination projects is not state of the art. EIA for desalination projects should include collection of comprehensive information on all environmental relevant impacts of desalination, conduction of monitoring activities, establishment of criteria for analysis of monitoring data, and finally the comparison of different water supply options against each other [18]. The impacts of open intakes can be mildened by a combination of screens and low intake velocity. Where topographic and geologic conditions make it possible, the option of horizontal drains below the seabed should be taken into account [19]. That way it is possible to minimize the impingement and entrainment of larger organisms. To avoid the entrainment of plankton organisms (eggs, larvae) intakes should be located into deeper waters, offshore, or underground (e.g. by using beach wells), i.e. away from productive areas. Co-location of desalination and power plants should be realized where possible. Pre-filtration with ultrafiltration (UF) or microfiltration (MF) membranes as alternative intake should be taken into consideration, since this option can significantly contribute to the reduction of chemical pre-treatment needs. A further possibility is given by irradiation of the intake water with UV light (200-300 nm). This technique allows for damaging the DNA structure of microorganisms and thus for disinfection of the intake water. Concerning the brine discharge, impacts from high salinity can be minimized by pre-diluting the brine with other waste streams. Co-location of desalination and power 
plants would allow for using power plant cooling water to blend the concentrate waste water from the desalination plant. Impacts of high temperature in the brine can be reduced by optimizing the heat dissipation from the waste stream to the atmosphere prior to the discharge into the water body (cooling towers) [18]. Multi-port diffuser can also be implemented to enhance the dilution and allow for a sound brine management [20]. Finally, the use of renewable energies like PV, Wind and particularly CSP -due to its ability to be operated round-the-clock- can contribute to produce clean and sustainable electricity and heat for the desalination plants, and to dramatically reduce the airborne emissions.

\section{ACKNOWLEDGMENTS}

The authors would like to thank the World Bank, which supports the MENA Regional Water Outlook Project, and the project partners Fichtner GmbH \& Co. KG and FutureWater.

\section{NOMENCLATURE}

\begin{tabular}{ll} 
BOO & Build, Own, Operate \\
BOOT & Build, Own, Operate, Transfer \\
CAPEX & Capital Expenditures \\
CSP & Concentrating Solar Power \\
DLR & Deutsches Zentrum für Luft- und Raumfahrt (German \\
& Aerospace Center) \\
DNA & Deoxyribonucleic Acid \\
DNI & Direct Normal Irradiance \\
EIA & Environmental Impact Assessment \\
FLH & Full Load Hour \\
GCM & Global Circulation Models \\
GIS & Geographic Information System \\
GHG & Greenhouse Gases \\
HFO & Heavy Fuel Oil \\
IPCC & Intergovernmental Panel on Climate Change \\
kWh & Kilowatt hour \\
LEC & Levelized Electricity Cost \\
LWC & Levelized Water Cost \\
MCM & Million Cubic Meters \\
MED & Multiple Effect Distillation \\
MENA & Middle East and North Africa \\
MF & Microfiltration \\
MSF & Multi-Stage Flash \\
MW & Megawatt \\
NG & Natural Gas \\
OPEX & Operational Expenditures \\
PPA & Power Purchase Agreement \\
RO & Reverse Osmosis \\
SW & Seawater \\
TVC & Thermal Vapor Compression \\
TWh & Terawatt hour \\
UF & Ultrafiltration \\
& \\
\hline
\end{tabular}




$\begin{array}{ll}\text { UV } & \text { Ultraviolet } \\ \text { y } & \text { Year }\end{array}$

\section{REFERENCES}

1. Trieb, F., Fichter, T., Moser, M., et al. "Desalination Using Renewable Energy, Task 2 - Energy Requirement”, MENA Regional Water Outlook, Part II, Online at: www.dlr.de/tt/menawater, March 2011

2. Sommariva, C., "Desalination and Advanced Water Treatment - Economics and Financing”, Book, Balaban Desalination Publications, 2010

3. CSP Today, www.csptoday.com, Online [2011]

4. Schillings, C., Mannstein, H., Meyer, R. (2004) Operational method for deriving high resolution direct normal irradiance from satellite data. Solar Energy, 76 (4), 475-484. (http://dx.doi.org/10.1016/j. solener.2003.07.038)

5. Hammer, A, Heinemann, D., Hoyer, C. Kuhlemann, R., Lorenz, E., Müller, R., Beyer, H.G., (2003): Solar Energy Assessment Using Remote Sensing Technologies, Remote Sensing of Environment. 86, 423-432. (http://dx.doi.org/10.1016/S0034-4257(03)00083-X)

6. Allal, H., et al., M., “Technology Review and Selection of CSP and Desalination Configurations adapted for Application in the Southern and Eastern Mediterranean Region” MED-CSD Final Report - WP1: Combined Solar Power and Desalination Plants: Techno-Economic Potential in Mediterranean Partner Countries

7. Trieb, F., Schillings C., O’Sullivan M., Pregger, T., Hoyer-Click, C., "Global Potential of Concentrating Solar Power", presented at the SolarPACES Conference 2009, Berlin, 2009

8. Dersch, J., Richter, C., „Wasserverbrauch und Wassereinsparung bei solarthermischen Kraftwerken”, presentation at the Sonnenkolloquium 2010

9. Fichtner, Fichtner Engineering and Consulting Services, personal communication [2011]

10. Eurelectric - Union of the Electricity Industry: Electricity Tariffs as of 1 January 2007 - Published Tariffs

11. GWI DesalData: www.desaldata.com, Desalination Markets 2010, Desalination Finance, 2011

12. Immerzeel, W., Droogers, P., Terink, W., "Water demand model report”, MENA Regional Water Outlook, 2011

13. Trieb, F., et al., AQUA-CSP: Concentrating Solar Power for Seawater Desalination. German Aerospace Center (DLR), Study for the German Ministry of Environment, Nature Conservation and Nuclear Safety, Stuttgart 2007, www.dlr.de/tt/aqua-csp

14. Trieb, F., Müller-Steinhagen, H., "Concentrating solar power for seawater desalination in the Middle East and North Africa”, Desalination, 220 (2008), 165-183 (http://dx. doi.org/10.1016/j.desal.2007.01.030)

15. Desaldata, 2011, www.desaldata.com, [Online, cited 10.05.2011]

16. GWI: GWI Desalination Market Forecast March: DesalForecastMarch2010.xls, 2010

17. Trieb, F., Müller-Steinhagen, H., Kern, J., Financing Concentrating Solar Power in the Middle East and North Africa - Subsidy or Investment?, Energy Policy 39 (2011) 307 - 317 (http://dx.doi. org/10.1016/j.enpol.2010.09.045) 
18. Lattemann, S., Höpner, T., "Environmental impact and impact assessment of seawater desalination”, Desalination, 220 (2008), 1-15

(http://dx.doi.org/10.1016/j.desal.2007.03.009)

19. Peters, T., Pinto, D., "Seawater intake and pre-treatment/brine discharge environmental issues”, Desalination, 221 (2008), 576-584

(http://dx.doi.org/10.1016/j.desal.2007.04.066)

20. Bleninger, T., Jirka, G.H., "Modeling and environmentally sound management of brine discharge from desalination plant”, Desalination, 221 (2008), 585-59 (http://dx.doi.org/10.1016/j.desal.2007.02.059) 
Paper accepted: 02.05.2013 